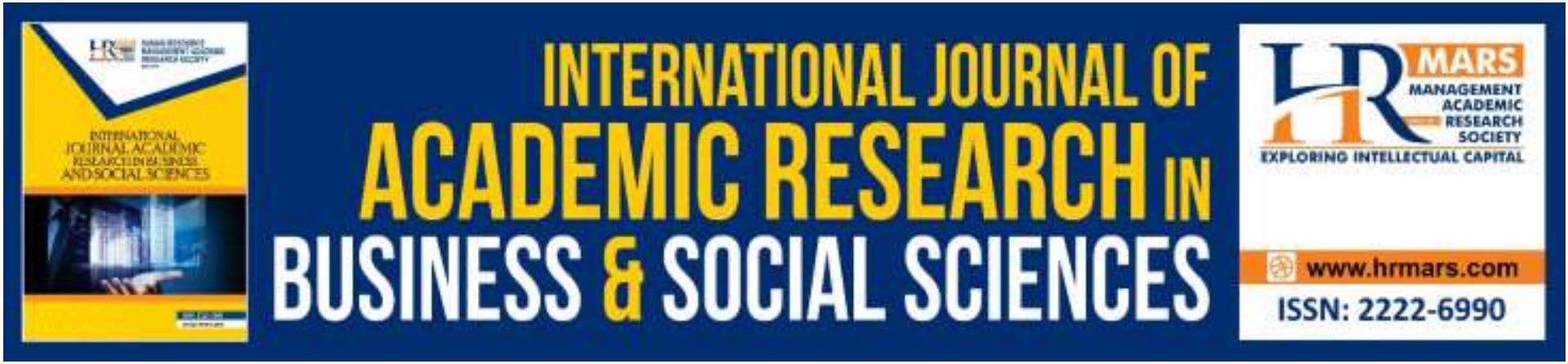

\title{
The Study of Type of Biotechnology Industry Trend According its State in Malaysia: Part A
}

\section{Chee Loong Teo, Huam Hon Tat}

To Link this Article: http://dx.doi.org/10.6007/IJARBSS/v9-i9/6413

DOI: $10.6007 /$ IJARBSS/v9-i9/6413

Received: 25 July 2019, Revised: 10 August 2019, Accepted: 30 August 2019

Published Online: 14 September 2019

In-Text Citation: (Teo \& Tat, 2019)

To Cite this Article: Teo, C. L., \& Tat, H. H. (2019). The Study of Type of Biotechnology Industry Trend According its State in Malaysia: Part A. International Journal of Academic Research in Business and Social Sciences, 9(9), 1184-1200.

Copyright: (C) 2019 The Author(s)

Published by Human Resource Management Academic Research Society (www.hrmars.com)

This article is published under the Creative Commons Attribution (CC BY 4.0) license. Anyone may reproduce, distribute, translate and create derivative works of this article (for both commercial and non-commercial purposes), subject to full attribution to the original publication and authors. The full terms of this license may be seen

at: http://creativecommons.org/licences/by/4.0/legalcode

Vol. 9, No. 9, 2019, Pg. 1184 - 1200

http://hrmars.com/index.php/pages/detail/IJARBSS

JOURNAL HOMEPAGE

Full Terms \& Conditions of access and use can be found at http://hrmars.com/index.php/pages/detail/publication-ethics 


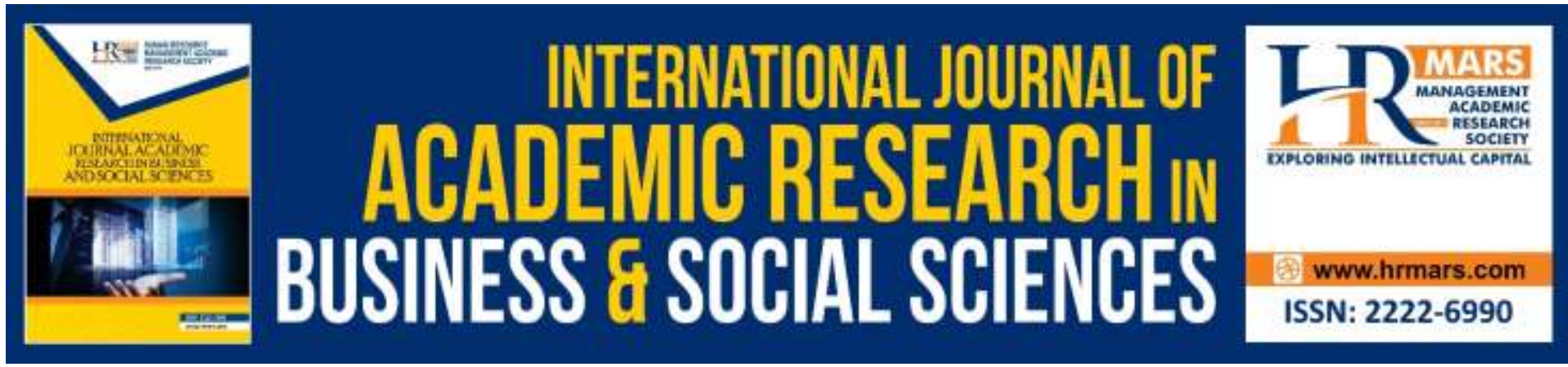

\title{
The Study of Type of Biotechnology Industry Trend According its State in Malaysia: Part A
}

\author{
Chee Loong Teo \\ Southern University College, Faculty of Business and Management, Jalan Selatan Utama, Off \\ Jalan Skudai, 81300 Skudai, Johor, Malaysia. \\ Diamond Star Biotechnology Sdn. Bhd., 85, Jalan Serampang, Taman Sri Tebrau, 80050, \\ Johor Bahru, Johor, Malaysia.
}

\section{Huam Hon Tat}

Putra Business School, 43400 UPM Serdang, Selangor Darul Ehsan, Malaysia.

\begin{abstract}
Recently, biotechnology industry gradually develops into a major and highlight potential industry in worldwide which is believe that will form a new generation in these industry field. Started from year 2005, Malaysia was officially established the Malaysian Biotechnology Corporation (MBC) which is focusing in development biotechnology field. As up to-date, the numbers of biotechnology company continuously develop. In this paper, 282 biotechnology company are focused and classified according its bioindustry type and accordance with Malaysia respectively. Johor, Kedah Kelantan, Malacca, Negeri Sembilan, Pahang, Perak, Sabah and Sarawak are the major focus on agricultural biotechnology (60-100\%), Penang and Selangor are developed more evenly in different biotechnology industry such as agricultural biotechnology (55 - 58\%), medical biotechnology $(27-35 \%)$ and industrial biotechnology (10 - 15\%), Terengganu focus on agricultural biotechnology (50\%) and industrial biotechnology (50\%) while Wilayah Kuala Lumpur even more focusing on medical biotechnology (46\%) compare with agricultural biotechnology (38\%) and industrial biotechnology (16\%).
\end{abstract}

Keywords: Biotechnology, States, AgBiotech, BioMedical, Biolndustrial.

\section{Introduction}

Biotechnology as an industry refers to the utilized of living organisms to improve the development of products for animal and human healthcare, food processing, agricultural production, renewable resources and environmental and industrial management (BIOTEK, 2001). The importance of the biotechnology industry as a key point of growth for the country economy, the Malaysian Government has invested in variety of biotechnology application such as human health, agriculture and related bioindustry field (BIOTEK, 2001). In 2001, Malaysia had propelled the transformation and biotechnology industry is one of the five core 
strategies to a highly industrialized country by 2020 (Malaysia, 2001; Ahmed, Umrani, Qureshi, \& Samad, (2018)Ahmed, Isa, Majid, Zin, \& Amin, 2017).

In addition, since 1990s Malaysia already aspired to enactment bioeconomy and biotechnology as one of the core engines of economic growth to use the rich of biodiversity and natural resources in Malaysia (Arujanan and Singaram, 2018; Ahmed, Majid, \& Zin, 2016). While, the government plays an important integral role in developing the industry and variety of incentives are in place for the private industry to be more actively involved to be collaborate with the government.

In 2005, Malaysia had launched the National Biotechnology Policy and lately launched the National Bioeconomy Programme in 2019. Malaysia has become the $1^{\text {st }}$ country for the launched of National Bioecunomy in South East Asia and $2^{\text {nd }}$ in Asia after China. Besides, Malaysia also very active in biosafety regulations and laws and major related legal instrument in place. Couple of success story has been recorded since the begin of the National Biotechnology Policy in term of contribution to Gross Domestics Product (GDP) via biotechnology industry and foreign companies' investment, job opportunity, however, this industry is not spared from challenges too (Arujanan and Singaram, 2018).

The biotechnology industries keep growing to be potential industry in the market. However, this is a valuable study in biotechnology industry unfortunately only minority of researchers contribute in this area. Thus, in this study an attempt was made to discuss about biotechnology company trend study according its states in Malaysia.

\section{Methodology}

\section{Study Area}

An emphasis of biotechnology company analysis is put on the following states in Malaysia: Johor, Kedah, Kelantan, Malacca, Negeri Sembilan, Pahang, Penang, Perak, Sabah, Sarawak, Selangor, Terengganu, Wilayah Persekutuan Kuala Lumpur, Perlis, Wilayah Persekutuan Labuan and Putrajaya.

\section{Classification}

In this study, the sample size is 282 biotechnology companies and grouped in three categories:

i) AgBiotech Based Biotechnology Company (agricultural biotechnology)

ii) BioMedical Based Biotechnology Company (medical biotechnology)

iii) Biolndustrial Based Biotechnology Company (industrial biotechnology)

The above categories are according its states: Johor, Kedah, Kelantan, Malacca, Negeri Sembilan, Pahang, Penang, Perak, Sabah, Sarawak, Selangor, Terengganu, Wilayah Persekutuan Kuala Lumpur, Perlis, Wilayah Persekutuan Labuan and Putrajaya.

\section{Material and Data Collection}

These analyses is mainly based on the data derived from Bioeconomy Corporation database, containing information on 282 biotechnology companies as well as AgBiotech, BioMedical and Biolndustrial in Malaysia. Then, all the data analysis via Microsoft Excel 365. 


\section{Results and Discussions}

Figure 1 and Figure 2 showed the numbers of biotechnology companies and its percentage in Johor state according type of bioindustry. In Johor, AgBiotech (18 companies, 78\%), Biolndustrial ( 5 companies, $22 \%$ ) and BioMedical (0 company, $0 \%$ ), which represents a nearly 4-fold compare AgBiotech than Biolndustrial. In Johor, from the data that showed that less BioMedical developed in this state.

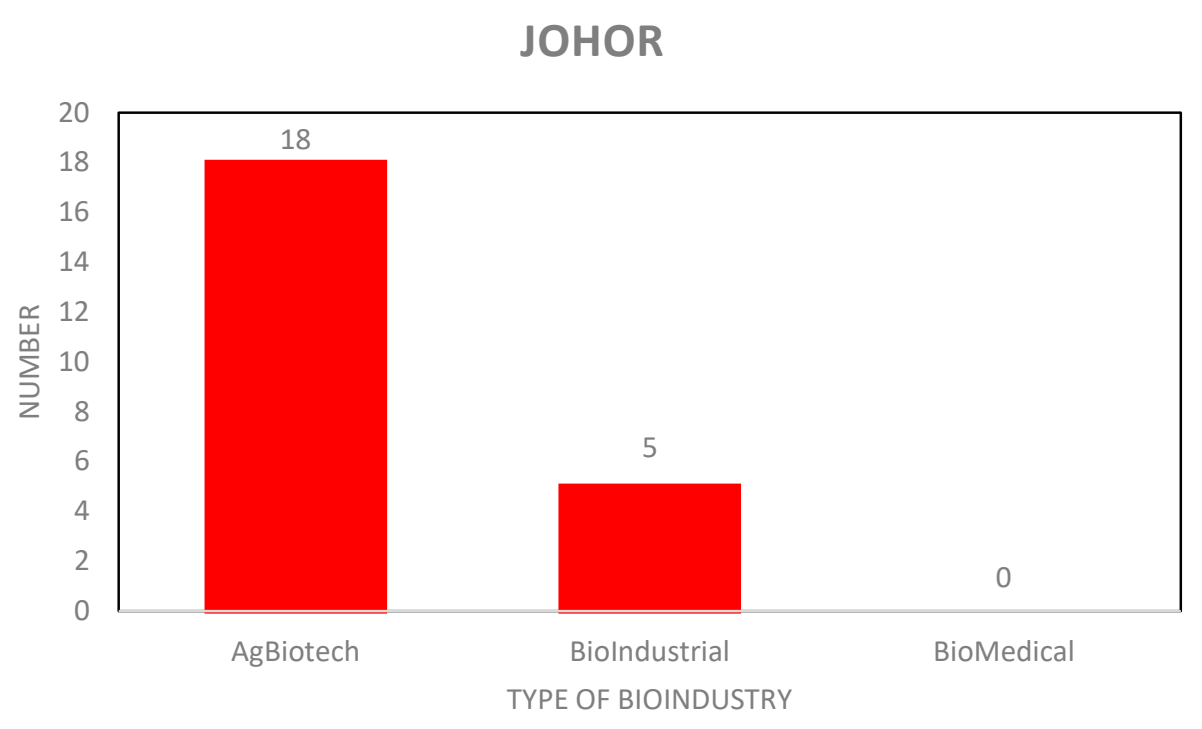

Figure 1 The nunber of biotechnology company according its bioindustry in Johor

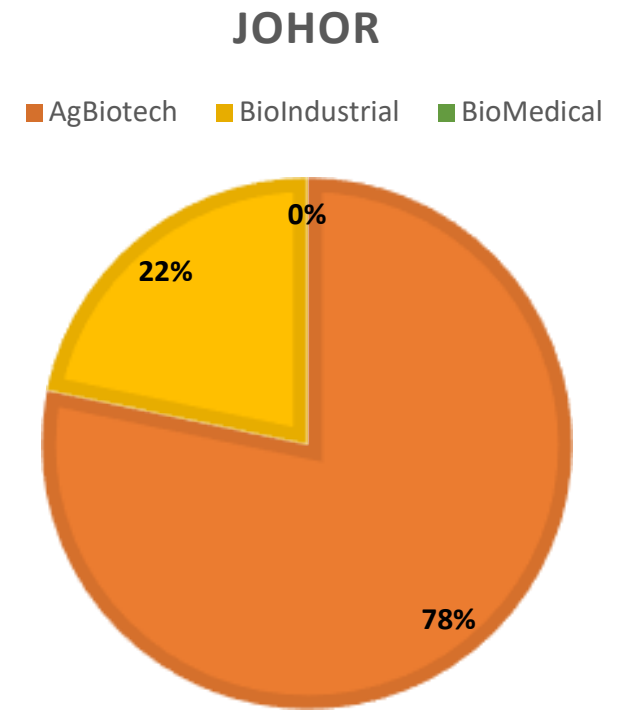

Figure 2 The percentage of biotechnology company according its bioindustry in Johor

Figure 3 and Figure 4 showed the numbers of biotechnology companies and its percentage in Kedah state according type of bioindustry. In Kedah, AgBiotech (1 company, 100\%), Biolndustrial (0 company, $0 \%$ ) and BioMedical (0 company, $0 \%$ ) which only one company with 
agricultural based biotechnology company registered. In Kedah, from the data that showed that less Biolndustrial and BioMedical developed in this state.

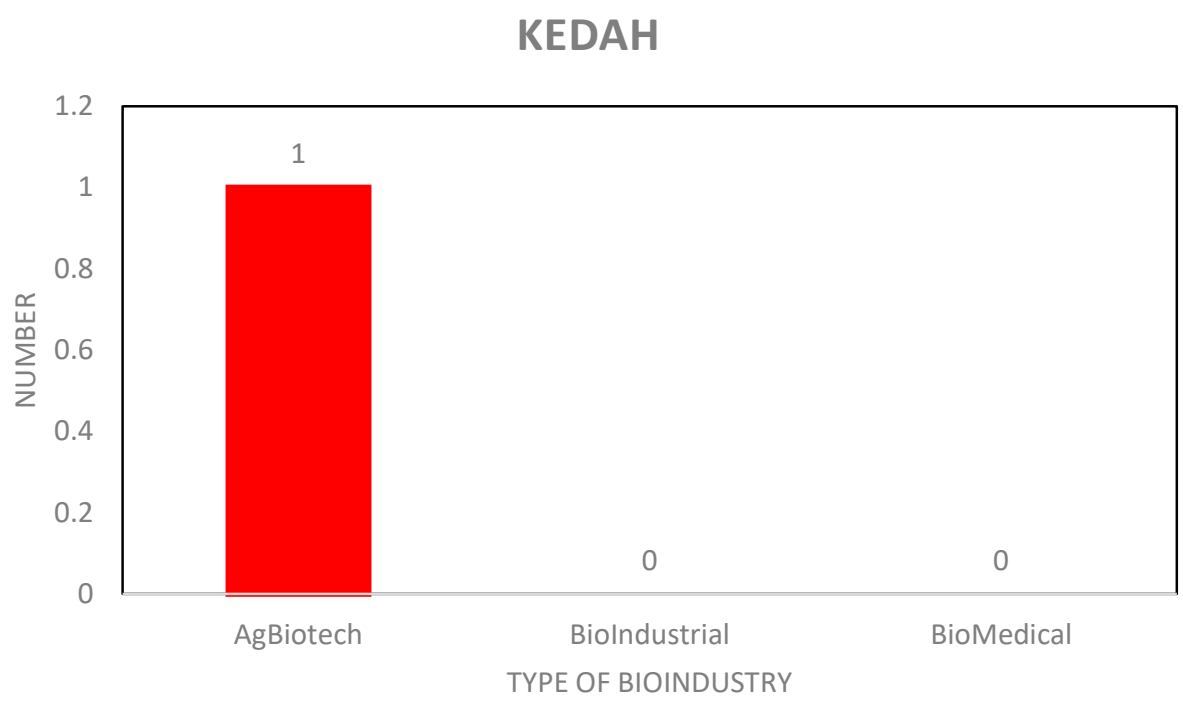

Figure 3 The nunber of biotechnology company according its bioindustry in Kedah

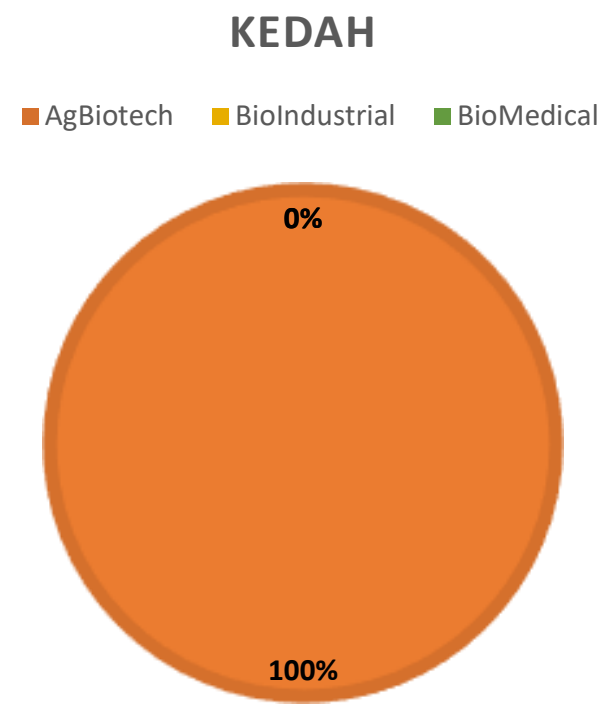

Figure 4 The percentage of biotechnology company according its bioindustry in Kedah

Figure 5 and Figure 6 showed the numbers of biotechnology companies and its percentage in Kelantan state according type of bioindustry. In Kelantan, AgBiotech (1 company, 100\%), Biolndustrial (0 company, 0\%) and BioMedical (0 company, 0\%). In Kelantan, same situation as Kedah, found only 1 biotechnology company with registered under agricultural. In Kelantan, from the data that showed that less Biolndustrial and BioMedical developed in this state. 


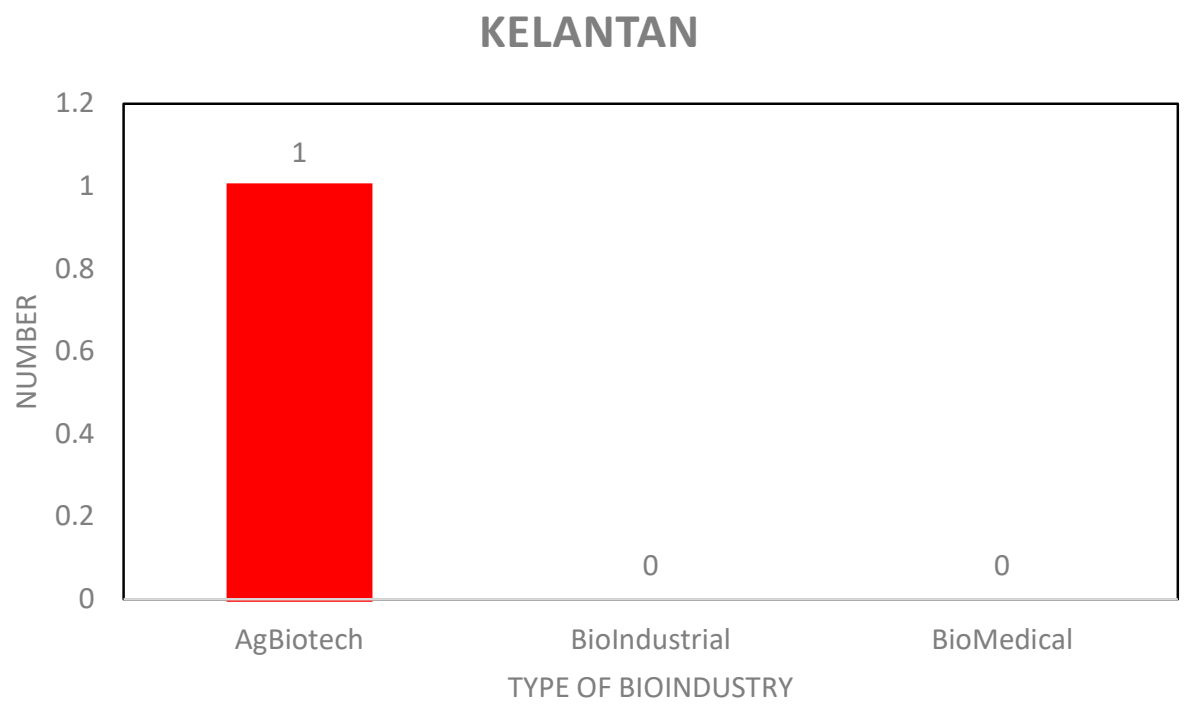

Figure 5 The nunber of biotechnology company according its bioindustry in Kelantan

\section{KELANTAN}

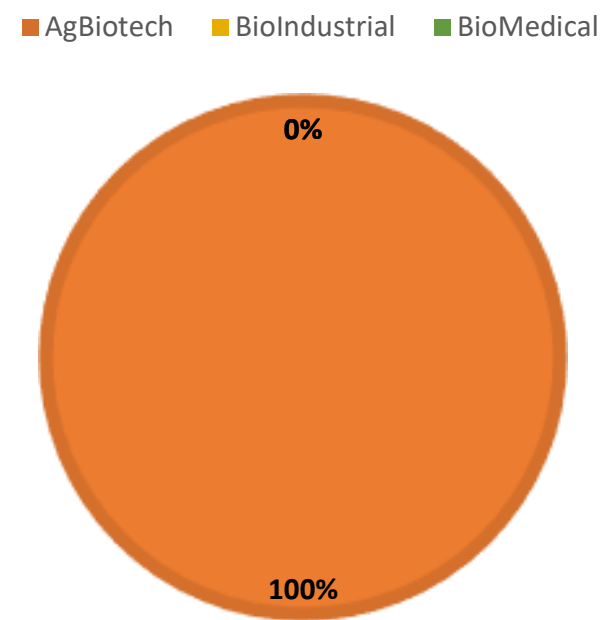

Figure 6 The percentage of biotechnology company according its bioindustry in Kelantan

Figure 7 and Figure 8 showed the numbers of biotechnology companies and its percentage in Malacca state according type of bioindustry. In Malacca, AgBiotech (3 companies, 60\%), Biolndustrial (1 company, 20\%) and BioMedical (1 company, 20\%), which represents a 3-fold compare AgBiotech than Biolndustrial and BioMedical respectively. In Malacca, the data showed 3 major biotechnology industries developed in this state. 


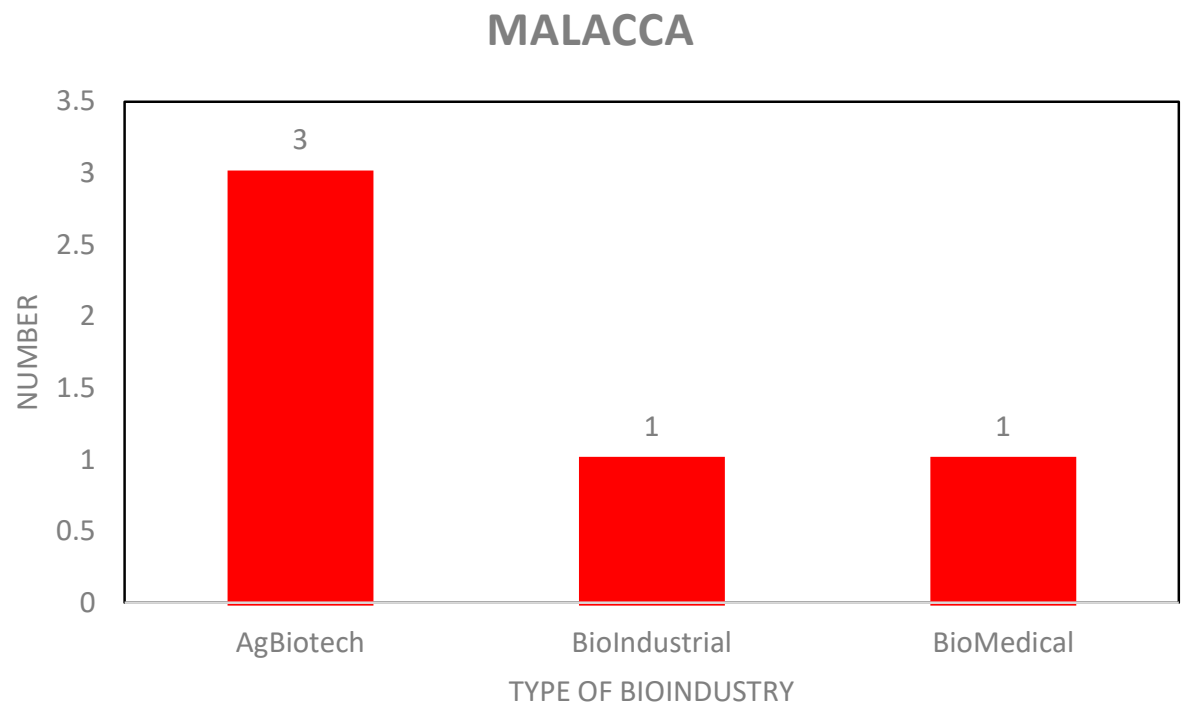

Figure 7 The nunber of biotechnology company according its bioindustry in Malacca

\section{MALACCA}

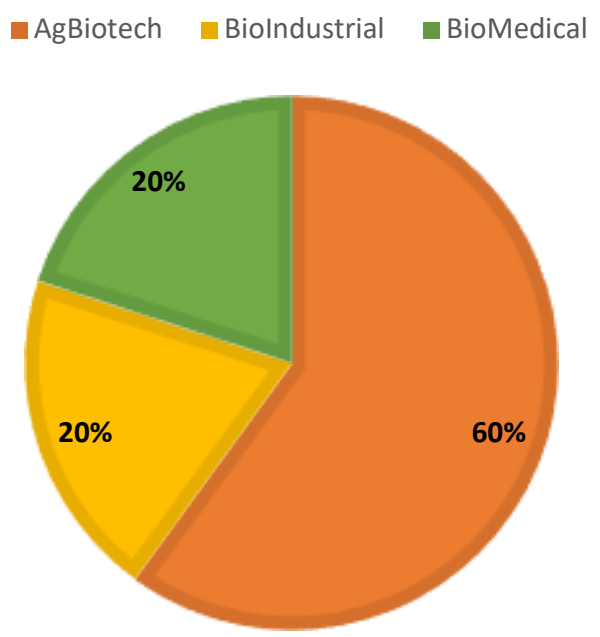

Figure 8 The percentage of biotechnology company according its bioindustry in Malacca

Figure 9 and Figure 10 showed the numbers of biotechnology companies and its percentage in Negeri Sembilan state according type of bioindustry. In Negeri Sembilan, AgBiotech (9 companies, $82 \%$ ), Biolndustrial (0 companies, $0 \%$ ) and BioMedical ( 2 companies, $18 \%$ ) which represents a nearly 4.5-fold compare AgBiotech than BioMedical. In Negeri Sembilan, the data showed the less Biolndustrial developed in this state. 


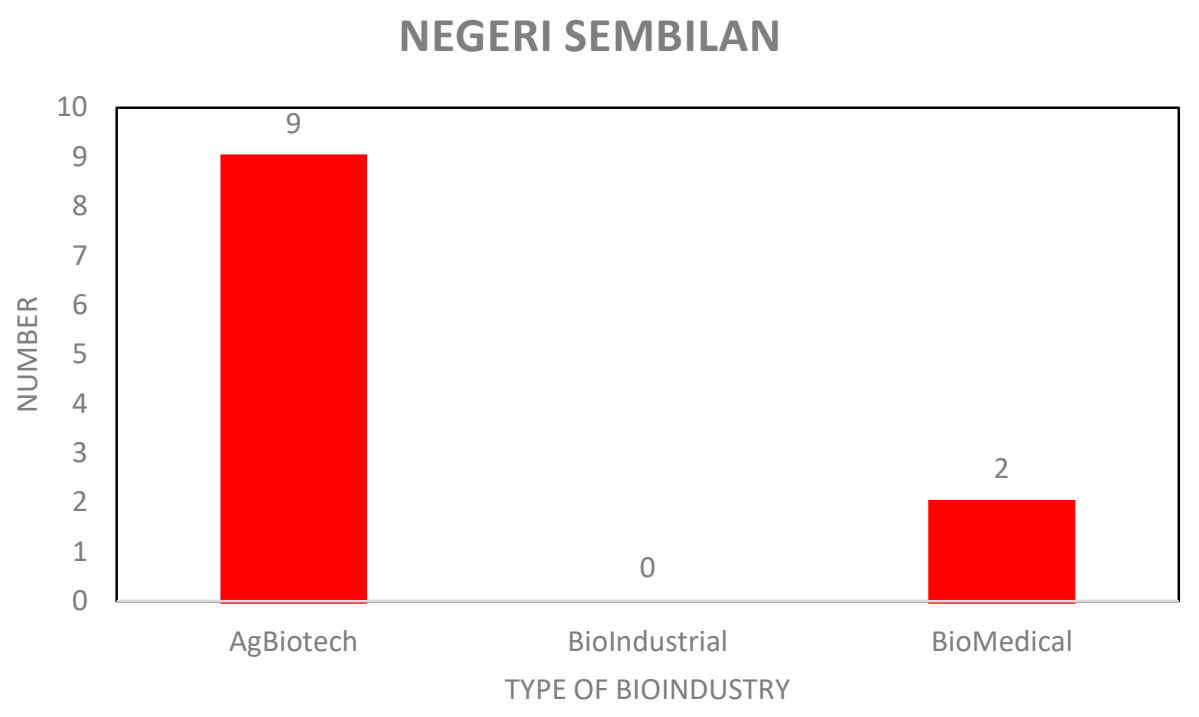

Figure 9 The nunber of biotechnology company according its bioindustry in Negeri Sembilan

\section{NEGERI SEMBILAN}

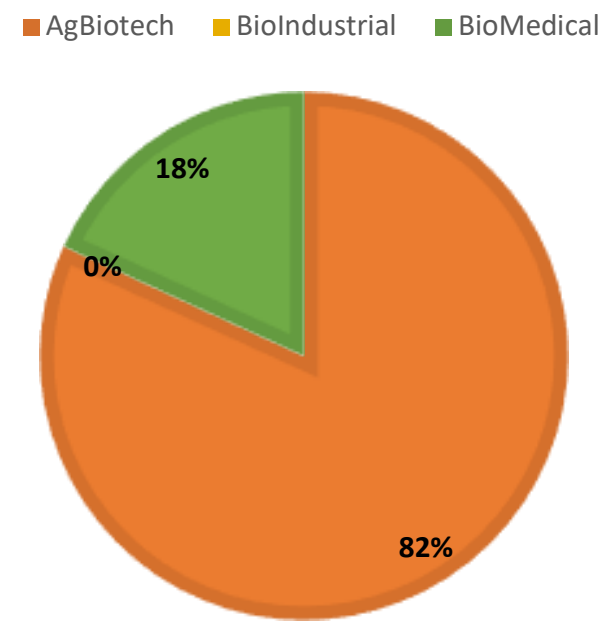

Figure 10 The percentage of biotechnology company according its bioindustry in Negeri Sembilan

Figure 11 and Figure 12 showed the numbers of biotechnology companies and its percentage in Pahang state according type of bioindustry. In Pahang, AgBiotech (2 companies, 67\%), Biolndustrial (1 company, 33\%) and BioMedical (0 company, 0\%) which represents a 2-fold compare AgBiotech than Biolndustrial. In Pahang, the data showed the less BioMedical developed in this state. 


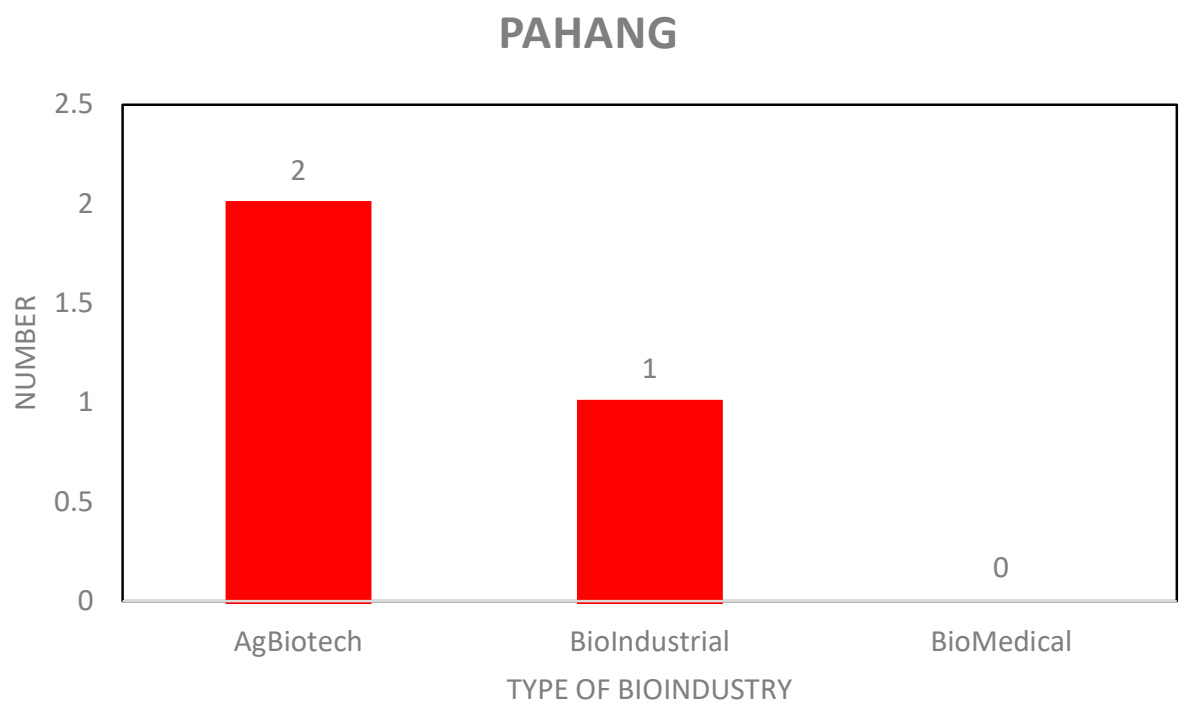

Figure 11 The nunber of biotechnology company according its bioindustry in Pahang

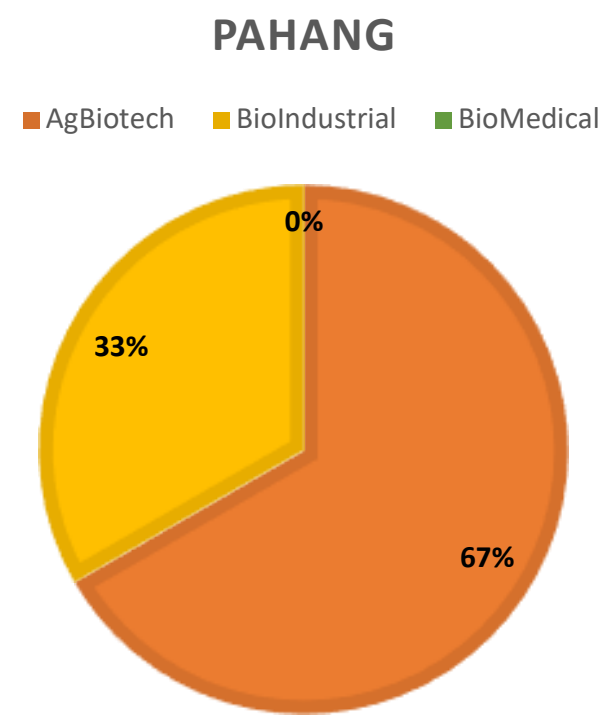

Figure 12 The percentage of biotechnology company according its bioindustry in Pahang

Figure 13 and Figure 14 showed the numbers of biotechnology companies and its percentage in Penang state according type of bioindustry. In Penang, AgBiotech (17 companies, 55\%), Biolndustrial (3 companies, 10\%) and BioMedical (11 companies, 35\%) which represents a nearly 5-fold compare AgBiotech than Biolndustrial and nearly 1-fold than BioMedical respectively. In Penang, the data showed the 3 major biotechnology industries developed in this state especially AgBiotech. 


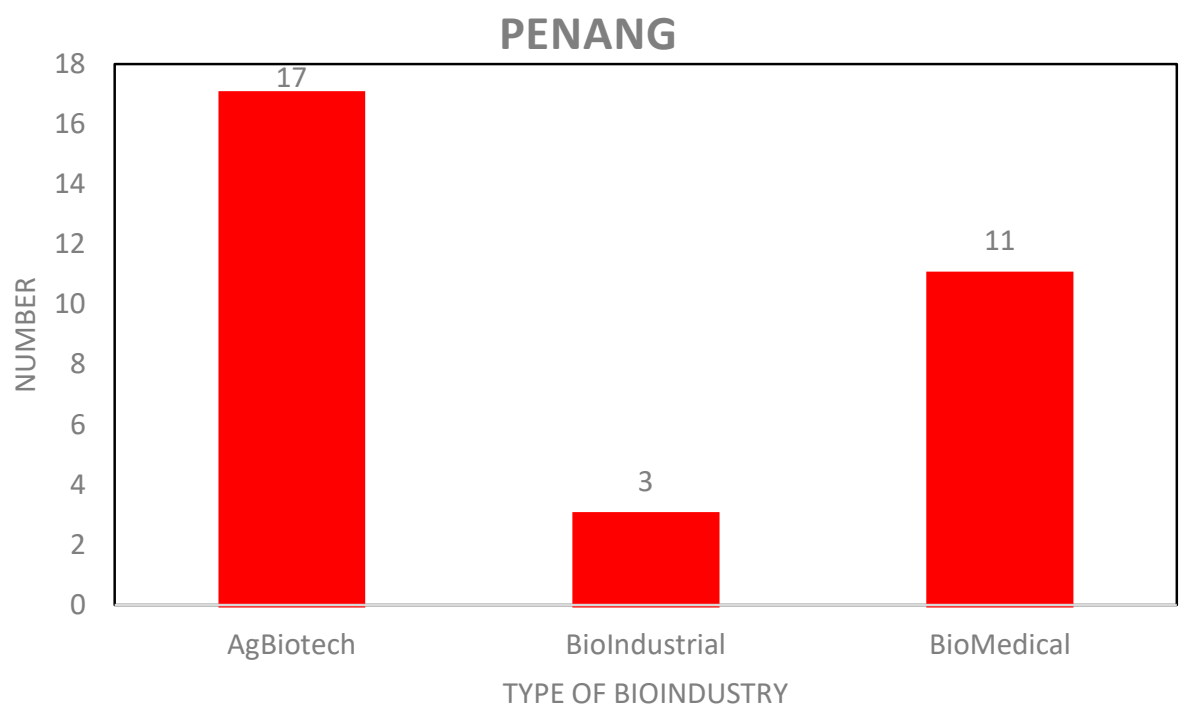

Figure 13 The nunber of biotechnology company according its bioindustry in Penang

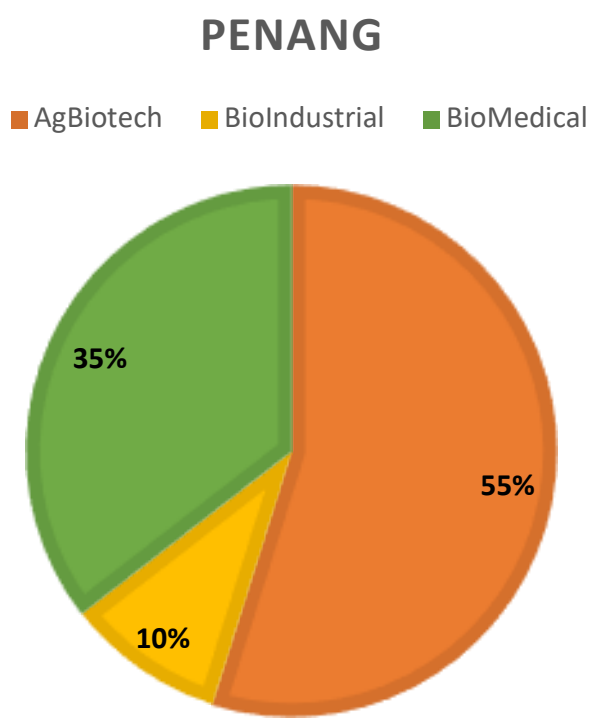

Flguere 14 The percentage of biotechnology company according its bioindustry in Penang

Figure 15 and Figure 16 showed the numbers of biotechnology companies and its percentage in Perak state according type of bioindustry. In Perak, AgBiotech (7 companies, 70\%), Biolndustrial (2 companies, 20\%) and BioMedical (1 company, 10\%) which represents a 3.5fold compare AgBiotech than Biolndustrial and 7-fold than BioMedical respectively. In Perak, the data showed the 3 major biotechnology industries developed in this state especially AgBiotech developed more. 


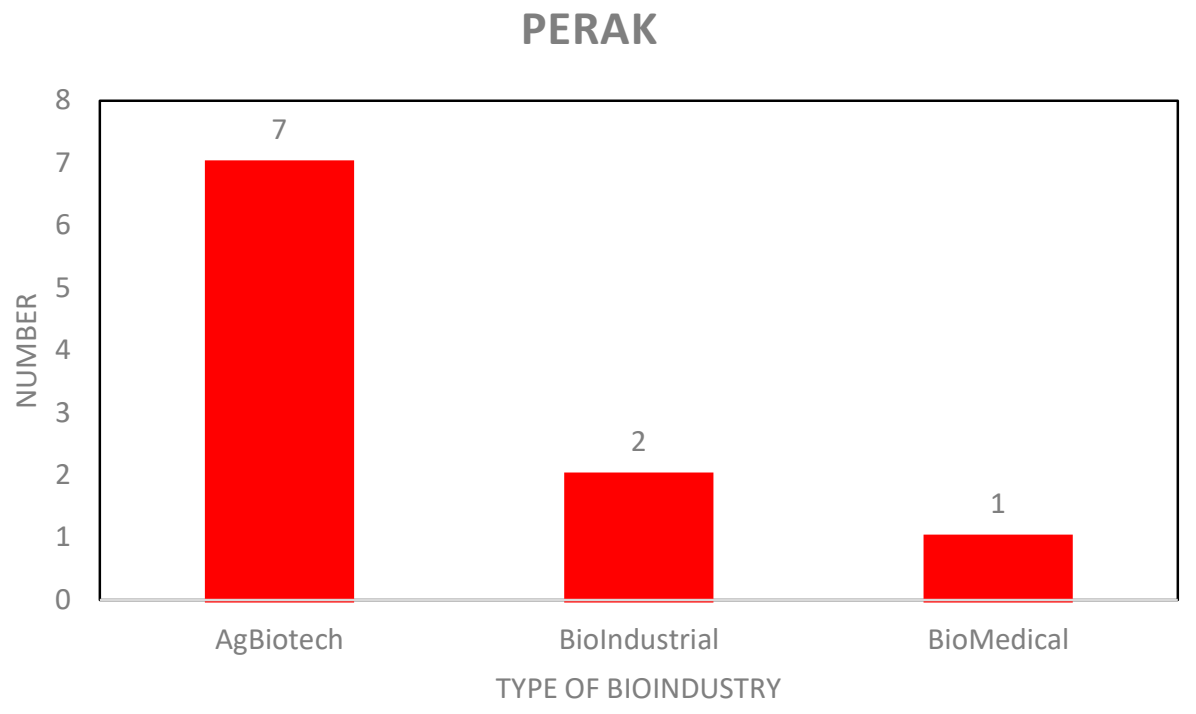

Figure 15 The nunber of biotechnology company according its bioindustry in Perak

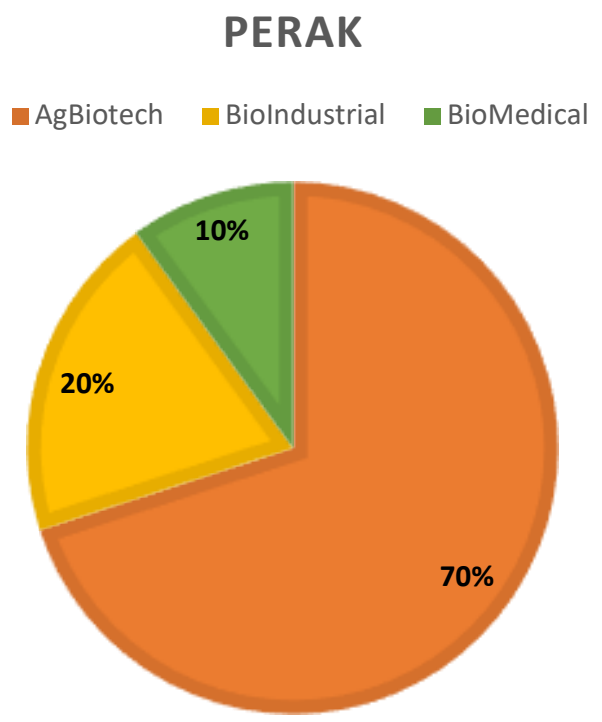

Figure 16 The percentage of biotechnology company according its bioindustry in Perak

Figure 17 and Figure 18 showed the numbers of biotechnology companies and its percentage in Sabah state according type of bioindustry. In Sabah, AgBiotech (10 companies, 91\%), Biolndustrial (1 company, 9\%) and BioMedical (0 company, 0\%) which represents a 10-fold compare AgBiotech than Biolndustrial. In Sabah, the data showed the less BioMedical developed in this state. 


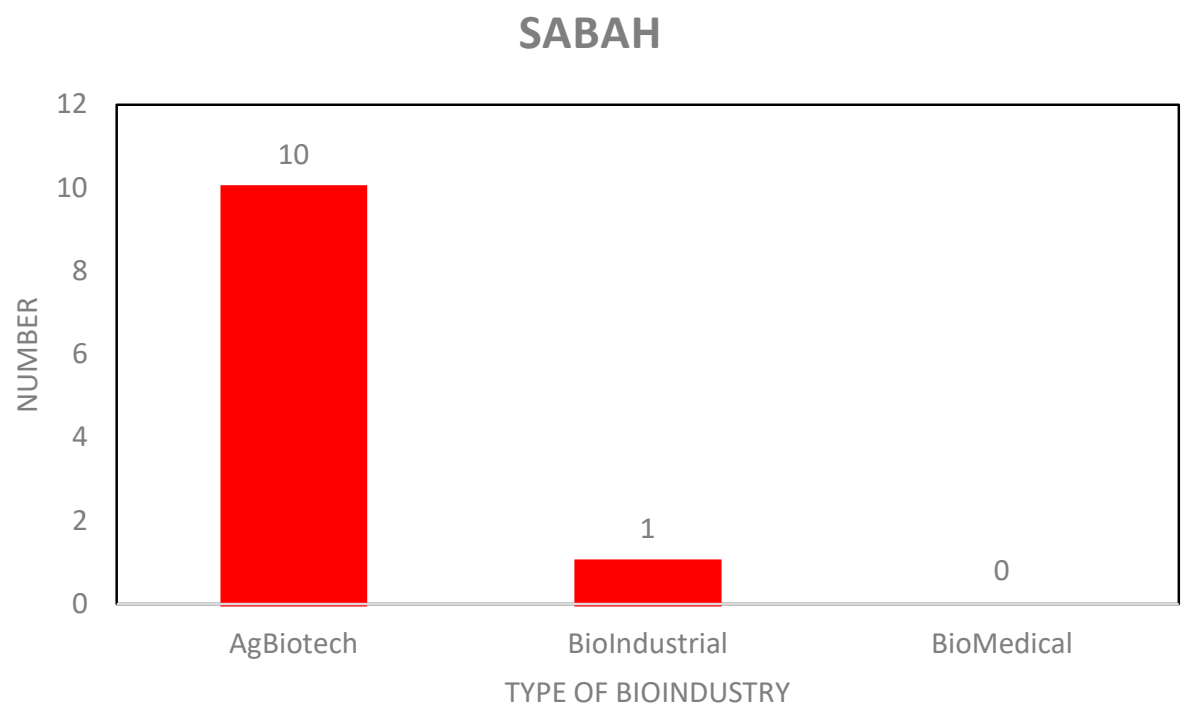

Figure 17 The nunber of biotechnology company according its bioindustry in Sabah

\section{SABAH}

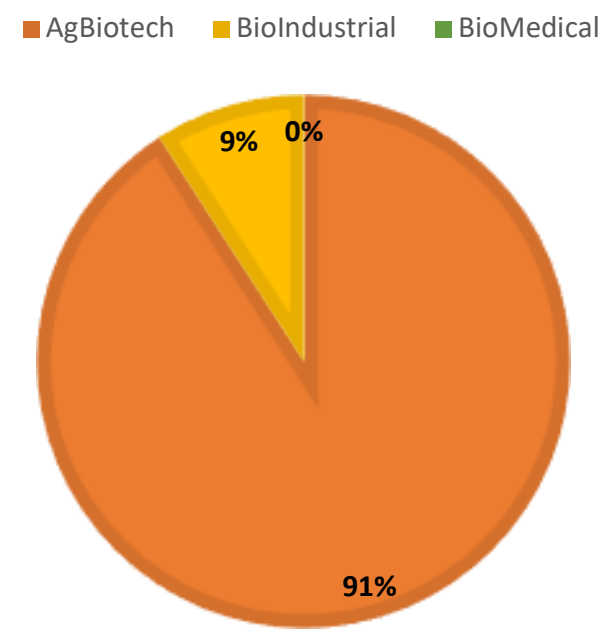

Figure 18 The percentage of biotechnology company according its bioindustry in Sabah

Figure 19 and Figure 20 showed the numbers of biotechnology companies and its percentage in Sarawak state according type of bioindustry. In Sarawak, AgBiotech (6 companies, 67\%), Biolndustrial (2 companies, 22\%) and BioMedical (1 company, 11\%) which represents a 3-fold compare AgBiotech than Biolndustrial and 6-fold than BioMedical respectively. In Sarawak, the data showed the 3 major biotechnology industries developed in this state especially AgBiotech field. 


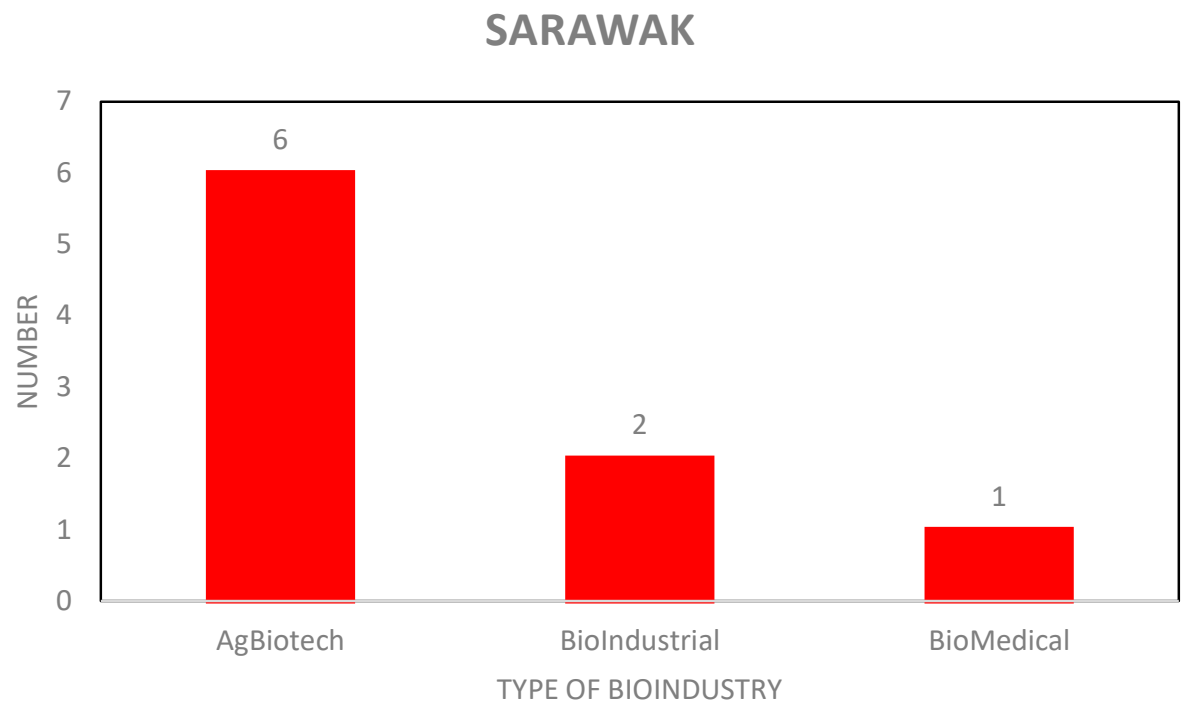

Figure 19 The nunber of biotechnology company according its bioindustry in Sarawak

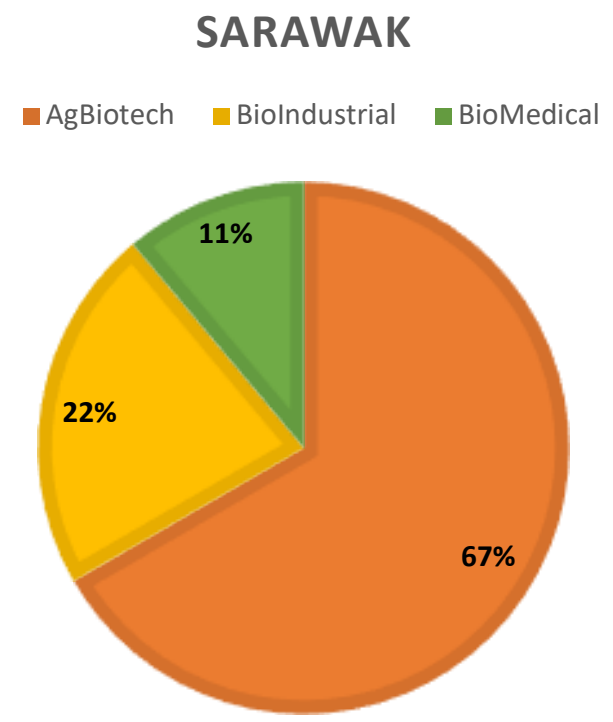

Figure 20 The percentage of biotechnology company according its bioindustry in Sarawak

Figure 21 and Figure 22 showed the numbers of biotechnology companies and its percentage in Selangor state according type of bioindustry. In Selangor, AgBiotech (59 companies, 58\%), Biolndustrial (15 companies, 15\%) and BioMedical (27 companies, 27\%) which represents a nearly 4-fold compare AgBiotech than Biolndustrial and nearly 2-fold than BioMedical respectively. In Selangor, the data showed the 3 major biotechnology industries developed in this state especially AgBiotech and BioMedical. 


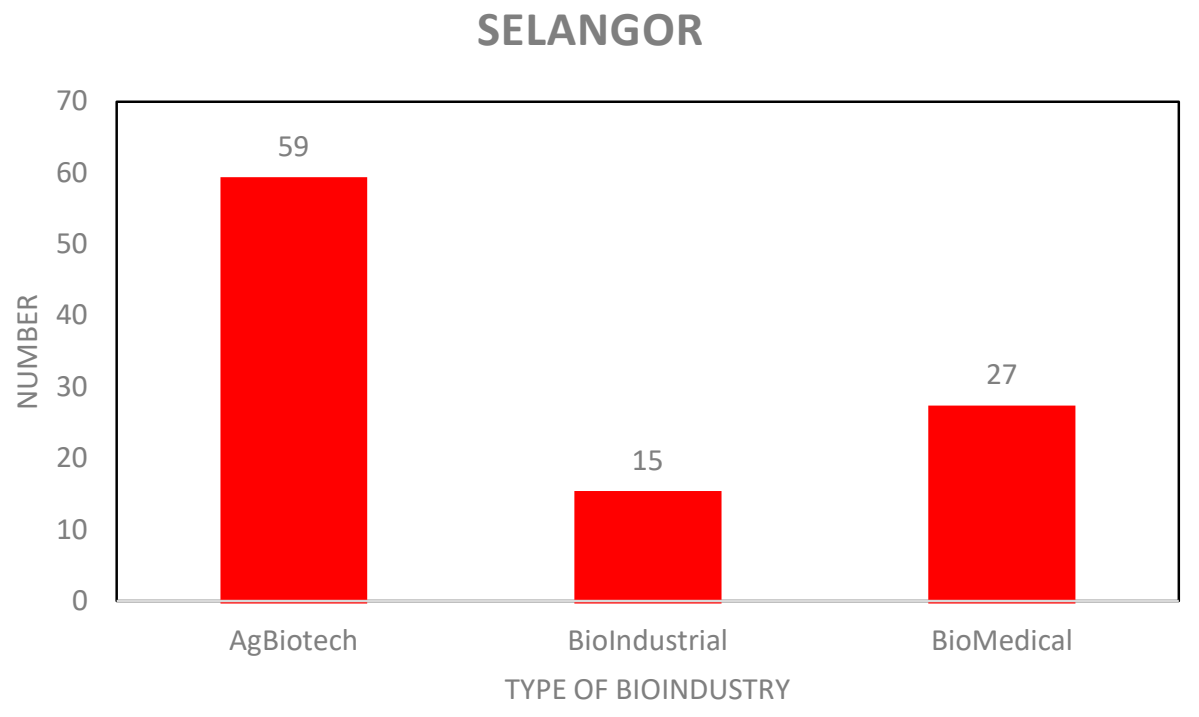

Figure 21 The nunber of biotechnology company according its bioindustry in Selangor

\section{SELANGOR}

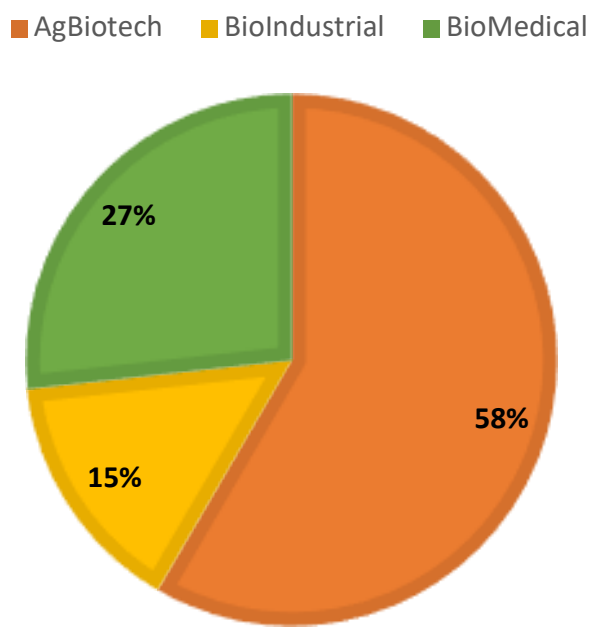

Figure 22 The percentage of biotechnology company according its bioindustry in Selangor

Figure 23 and Figure 24 showed the numbers of biotechnology companies and its percentage in Terengganu state according type of bioindustry. In Terengganu, AgBiotech (1 company, $50 \%$ ), Biolndustrial ( 1 company, 50\%) and BioMedical (0 company, $0 \%$ ) which represents only developed AgBiotech and Biolndustrial field. In Terengganu, the data showed the less BioMedical developed in this state. 


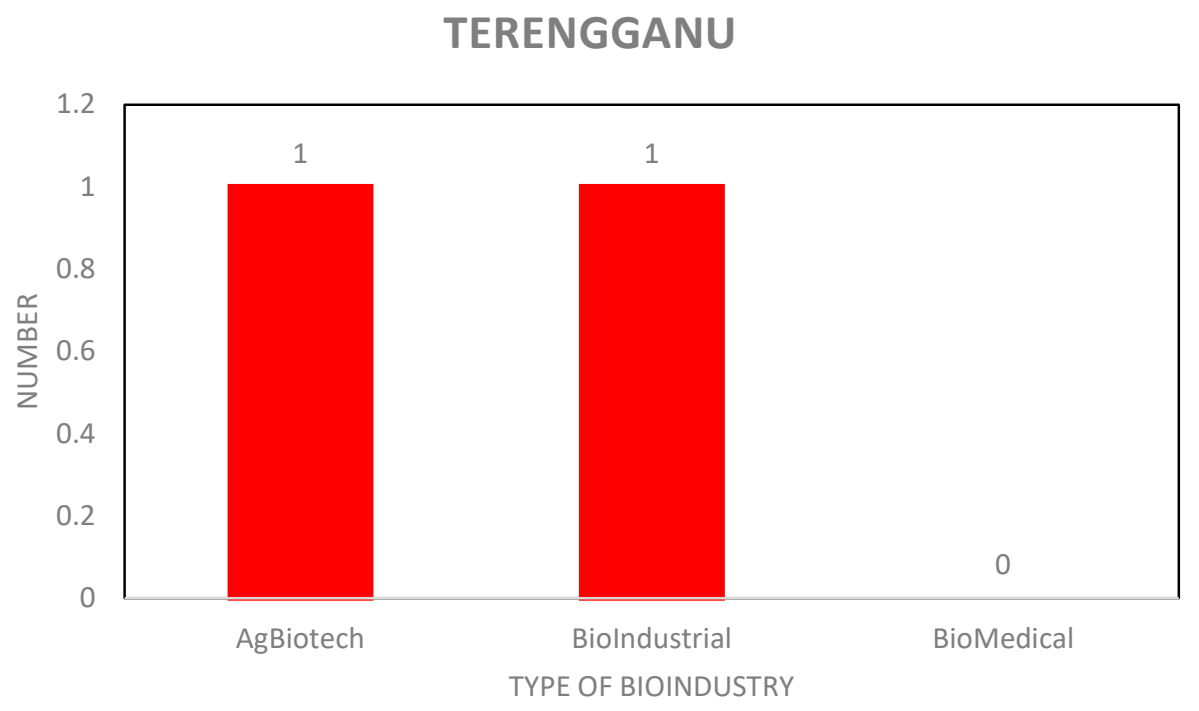

Figure 23 The nunber of biotechnology company according its bioindustry in Terengganu

\section{TERENGGANU}

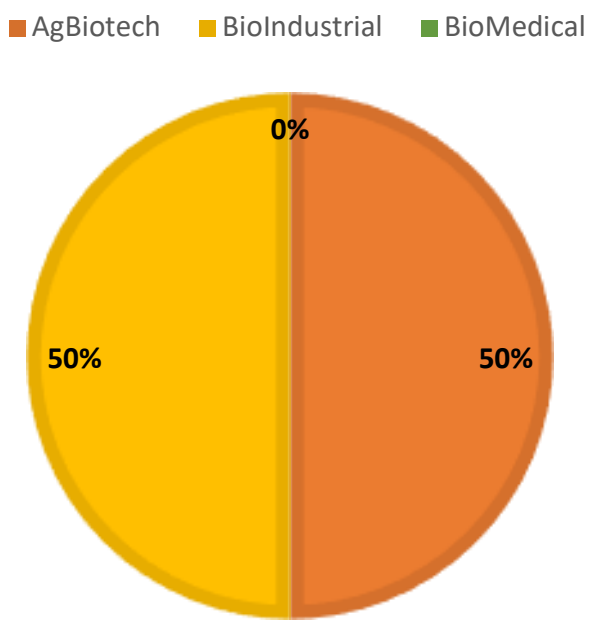

Figure 24 The percentage of biotechnology company according its bioindustry in Terengganu

Figure 25 and Figure 26 showed the numbers of biotechnology companies and its percentage in Wilayah Persekutuan Kuala Lumpur according type of bioindustry. In W. P. Kuala Lumpur, AgBiotech (28 companies, 38\%), Biolndustrial (12 companies, 16\%) and BioMedical (34 companies, $46 \%$ ) which represents a nearly 1-fold compare BioMedical than AgBiotech and nearly 3-fold than Biolndustrial respectively. In Wilayah Persekutuan Kuala Lumpur, the data showed the 3 major biotechnology industries developed in this state especially BioMedical field. 


\section{W. P. KUALA LUMPUR}

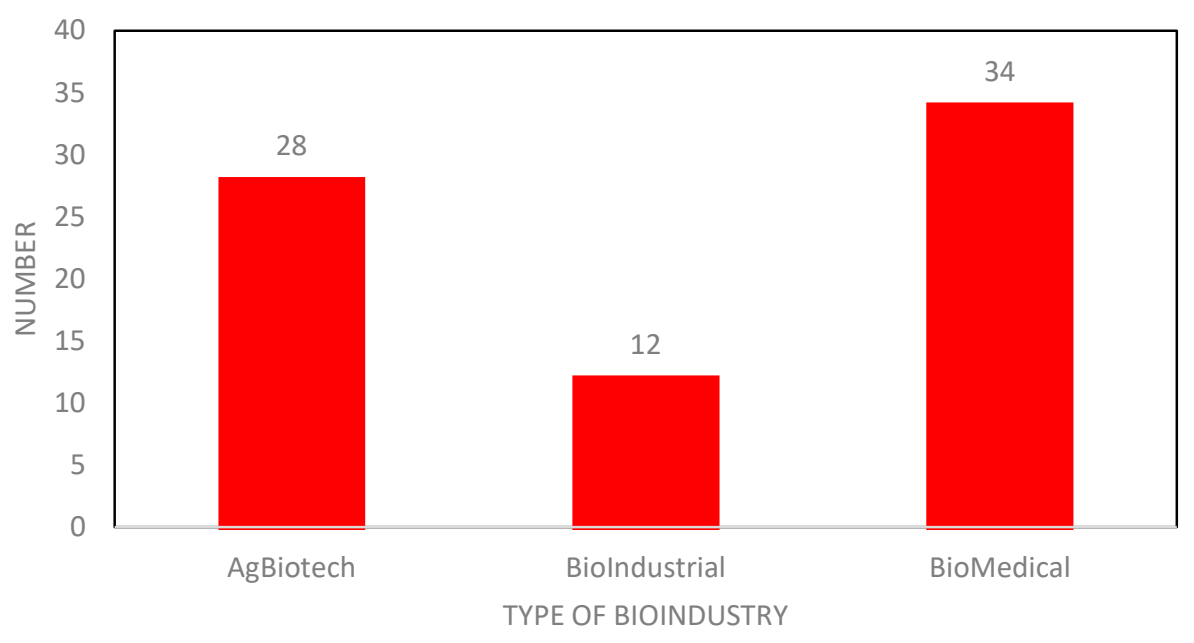

Figure 25 The nunber of biotechnology company according its bioindustry in W.P. Kulala Lumpur

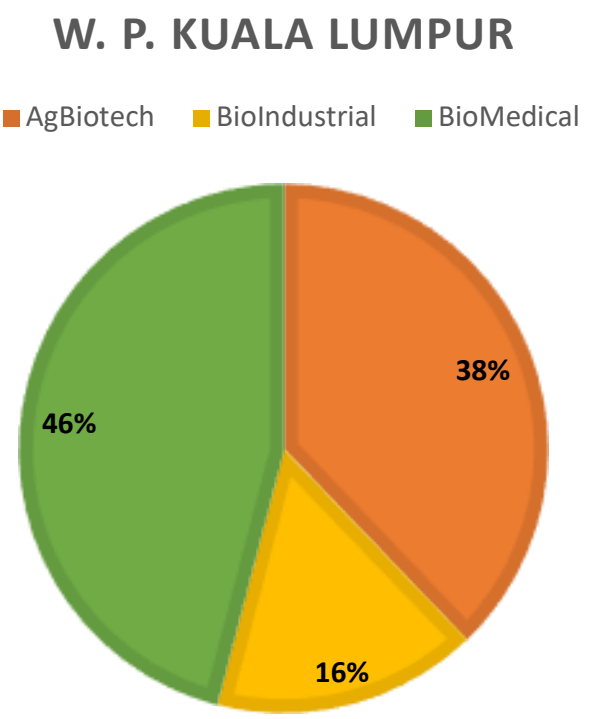

Figure 26 The percentage of biotechnology company according its bioindustry in W.P. Kuala Lumpur

Besides, from the data collection, three locations found that less biotechnology company developed and registered in Perlis, Wilayah Persekutuan Labuan and Putrajaya.

\section{Conclusion}

The distribution of biotechnology industries (AgBiotech, BioMedical and Biolndustrial) depend the location or states in Malaysia. In this research, AgBiotech (agricultural biotechnology) industry are the larger percentage in Malaysia due to rich of natural resources and its stable climate. However, this research only provided short discussion regard the distribution of types biotechnology companies in Malaysia according its states and even more 
relationships between variety factors and variables will be discussed and studies in future papers.

\section{Acknowledgement}

${ }^{1}$ Southern University College, Faculty of Business and Management, Jalan Selatan Utama, Off JalanSkudai, 81300 Skudai, Johor, Malaysia.

2Diamond Star Biotechnology Sdn. Bhd., Jalan Serampang, Taman Sri Tebrau, 80050, Johor Bahru, Johor, Malaysia.

${ }^{3}$ Putra Business School, 43400 UPM Serdang, Selangor Darul Ehsan, Malaysia.

${ }^{4}$ Malaysian Bioeconomy Development Corporation Sdn. Bhd.

\section{Corresponding Author}

Teo Chee Loong, anthony1109@hotmail.my, ${ }^{1}$ Southern University College, Faculty of Business and Management, Jalan Selatan Utama, Off JalanSkudai, 81300 Skudai, Johor, Malaysia. ${ }^{2}$ Diamond Star Biotechnology Sdn. Bhd., Jalan Serampang, Taman Sri Tebrau, 80050, Johor Bahru, Johor, Malaysia.

\section{References}

Ahmed, U., Isa, N. M., Majid, A. H. A., Zin, M. L. M., \& Amin, B. M. (2017). Towards understanding work engagement: can HR really buffer HR? Test of a moderated model. International Journal of Economic Research, 14(20), 1-18.

Ahmed, U., Majid, A. H. A., \& Zin, M. L. M. (2016). HR Moderating HR: Critical link between Developmental HR Practices and work engagement in a Moderated Model. Management Review: An International Journal, 11(2), 4-22.

Ahmed, U., Umrani, W. A., Qureshi, M. A., \& Samad, A. (2018). Examining the links between teachers support, academic efficacy, academic resilience, and student engagement in Bahrain. International Journal of Advanced and Applied Sciences, 5(9), 39-46.

BIOTEK. (2001). Priority setting in biotechnology under 8th Malaysia Plan ( $2^{\text {nd }}$ ed.). Putrajaya: the Ministry of Science, Technology and Innovation (MOSTI).

Mahaletchumy, A., Muthu, S. (2018). The biotechnology and bioeconomy landscape in Malaysia. New Biotechnology. 40 (25), 52-59.

Malaysia. (2001). 8th Malaysia Plan, 2001-2005. Kuala Lumpur: Economic Planning Unit, Prime Minister's Department. 